\title{
Die nuwe omdigting van die Psalms in Afrikaans as kreatiewe werk ${ }^{1}$
}

\section{T.T. Cloete}

Departement Afrikaans \& Nederlands

(Buitengewone Hoogleraar)

Potchefstroomse Universiteit vir $\mathrm{CHO}$

POTCHEFSTROOM

\section{Abstract \\ The versification of the Psalms in Afrikaans as creative work}

Three of the Reformed Protestant (Afrikaans) churches appointed an interdenominational commission to monitor a new versification of the Psalms in Afrikaans. This versification is to be sung in church services and at other devotional meetings. This versification is a task jointly undertaken by the poet, the theologian and the musicologist.

With the help of exegetes the poet is in the first instance compelled to be completely faithful to the Biblical Psalm. Faithfulness to the Bible does not only mean being faithful to the contents, but also to the structure of the Psalms. The 150 Psalms in the Bible each has, like any good work of literature, a definite structure, so that in order to know what is said, one also has to have insight into how it is said. The poet working on a versification of a Psalm to be sung in church services should be faithful to this "what" and "how" if he wants to be faithful to the Scriptures.

In the second instance the poet is limited in many ways by the melodies of the Psalms with their intricate patterns of verse and strophe. Being subservient to the melody is just as difficult for the poet as being subservient to the Scriptures and much more exacting.

In Afrikaans the versification by Totius is regarded as a part of Afrikaans literature. Its publication in the thirties coincided with a renewal in Afrikaans poetry. As a result of the development of

1 Verwerkte weergawe van ' $n$ lesing gehou by die Intemasionale Konferensie $\infty$ "Christendom en literatuur by die eeuwending". Potchefstroom. Augustus 1995. 
Afrikaans during the past century, the latest Bible translation and the most recent knowledge foregrounded by theological research, it has become necessary to work on a new versification of the Psalms. The aim is to rewrite these poems in a simple structured form of Afrikaans which can indeed be sung with ease.

\section{Inleidend}

Drie van die Protestants-Gereformeerde Kerke' het 'n interkerklike komitee gestig wat moet toesien dat die Psalms opnuut in Afrikaans berym word vir die kerksang en vir ander gewyde geleenthede. Dit is ' $n$ werk waaraan die digter, die teoloog en musikoloog saamwerk.

Die digter is in die eerste plek verplig om, met behulp van eksegete, volkome getrou aan die Bybelse Psalm te wees. Getrouheid aan die Bybel beteken nie alleen inhoudelike getrouheid nie maar ook getrouheid aan die struktuur van die Psalms. Die 150 Psalms van die Bybel het elkeen, soos elke goeie literêre werk, 'n duidelike struktuur, en as ons wil weet wat daar staan, moet ons ook insien hoe dit daar staan. Die digter wat die Psalms bewerk vir die kerksang, moet getrou wees aan daardie "wat" en "hoe" as hy Skriftuurlik getrou wil wees.

In die tweede plek word die digter op talle maniere gebind deur die melodieë van die Psalms met hulle ingewikkelde strofe- en verspatrone. Gehoorsaamheid aan die melodie is vir die digter ewe moeilik as die Skrifturlike gehoorsaamheid en baie meer veeleisend. Die melodie skryf aan die digter voor hoe lank die strofes van 'n Psalm moet wees, hoe lank die versreëls moet wees en hoe die verse binne 'n strofe gegroepeer moet word in substrofes. Verder bepaal die melodie wat die metrum en ritme en die rymskema van elke Psalm moet wees.

Die Psalms is van die tyd van hulle ontstaan af gesing, en vandag nog is die sing van die Psalms een van die belangrikste onderdele van die erediens waaraan die gemeentelid hardop en persoonlik meedoen.

Hoewel die Psalms oud is en uit 'n antieke tyd kom, is hulle van toepassing op die mens van vandag. Die Psalms bevat omtrent elke godsdienstige ervaring van die mens. Daarom is die bewerking van die Psalms in talle Westerse tale 'n integrale deel van die literatuur van daardie tale. Dit is byvoorbeeld die geval in die Nederlandse literatuur, wat van die vroegste tyd af talle digterlike

2 Die Nederduitse Gereformeerde Kerk, die Nederduitsch Hervormde Kerk van Afrika en die Gereformeerde Kerke in Suid-Afrika. 
bewerkings van die Psalms opgelewer het. Ook in die Engelse literatuur het die Psalms reeds baie aandag gekry as deel van die Engelse literatuurskat. IIn Afrikaans word die Totiusberyming as deel van die Afrikaanse literatuur beskou en die verskyning daarvan het in die dertigerjare saamgeval met die poësievernuwing in Afrikaans. Op grond van die ontwikkeling van Afrikaans in die afgelope eeu, die jongste Bybelvertaling en nuwe kennis wat die teologie deur navorsing opgedoen het, het dit nodig geword om 'n nuwe Psalmbewerking te mak. Dit is die strewe om hierdie Psalmbewerking in die eenvoudigste Afrikaans en in 'n hoogs singbare Afrikaans om te dig.

Om die Psalms vir die kerksang te bewerk, is 'n baie moeiliker taak as die skryf van 'n persoonlike gedig, maar dit is ook 'n baie kreatiewe dissipline, en 'n groot avontuur.

\section{Die eise aan die digter-vertaler/vertolker}

Elkeen wat gedigte skryf, weet dat die digter by die skryf van die gedig, al skrywende, elke oomblik, van tydstip tot tydstip, gelyktydig met 'n tiental komponente rekening moet hou; hy moet tien dinge tegelyk saamdink op een tydstip, en wat dit nog meer gekompliseer maak, is dat party van hierdie tien dinge konseptueel of redelik is, abstrak, ander is weer sintuiglik, konkreet, of selfs liggaamlik, soos ons ervaring van die ritme, wat verband hou met ons hartklop. Die digter moet op die konseptuele vlak alleen rekening hou met die baie betekenisse of funksies van byna elke woord waarmee hy werk, gekies uit 'n haas ontelbare aantal moontlikhede; hy moet rekening hou met die klank van die woord, met die intonasie van die sin, met die ritme van die taal, met die lettergreeptelling van die vers (hy moet, soos Leibniz dit gestel het, kan tel sonder dat hy weet hy tel), hy moet rekening hou met daardie wonderlike taalverskynsel van die sterker en swakker klemtone van die lettergrepe van die woorde, hy moet rekening hou met die sintagmas en die sintaksis in sy geheel, met die sins- en versfrasering, die ruspunte of stiltes tussen die woorde, die versbou, die strofebou, die grammatikale tyd en baie meer.

By die omdigting van die Psalms wat gesing word in die erediens van ons Protestants-Gereformeerde kerke is die digter onderworpe aan nog baie meer dissiplines as die oorvloedig baie wat ek genoem het. Hy is trouens as digter dan selfs nie eers meer op sy eentjie doenig nie. Daar is 'n hele paar ander persone wat saam met hom seggenskap het in wat hy doen. Daar is eerstens die oorspronklike Psalmdigter na wie hy moet luister en wie se Psalm hy so getrou moontlik moet weergee; tweedens is daar die eksegeet wat moet help met die interpretasie van die oorspronklike Psalm en wat tewens die kenner is van die oorspronklike taal waarin die Psalms geskryf is. Dan is daar nog die komponis se melodie, in baie gevalle 'n Geneefse melodie wat oorspronklik vir 'n Franse 
teks gekomponeer is, en dan kom die digter wat die Psalms omdig pas as vierde persoon by. Ons moet hom eintlik maar kortweg die digter-vertaler/vertolker noem.

Vir die digter-vertolker is die omdigting van die Psalms met die oog op die kerksang 'n groot avontuur, maar die werkwyse by die herskryf van die Psalms vir die kerksang verskil heeltemal van die werkwyse by die skryf van sy eie gedigte, want hy is onniddellik onderworpe aan voorskrifte wat hy glad nie ken by die skryf van sy eie werk nie.

Naas die dwingende eis van getrouheid aan die Bybelteks wat aan die digtervertolker gestel word, is daar daardie baie addisionele eise of voorskrifte, wat geld vir elke digter, plus nog 'n hele aantal ander wat ek nog nie eers genoem het nie. Ek kyk net na 'n paar hiervan.

\section{Struktuur en handelingsverloop}

Ek begin by wat ek die handelingsverloop van die Psalms wil noem, die verloop van die gebed, of die smeking, of die skuldbelydenis, die lofsang, oproep, getuienis of wat ook al. Vir die verstaan van die Bybelse Psalms geld wat vir elke literêre werk geld, naamlik dat ons alleen kan verstaan wat daar staan as ons insien hoe dit daar staan, omdat die "hoe" 'n plus toevoeg tot die "wat". Deur alle wisselende paradigmas, konstruksies en dekonstruksies, deur alle -ismes en vergismes heen bly dit aanwysbaar dat die "hoe" van die literêre werk wonderlike dinge toevoeg tot die teks. Pas toe ek begin het met die omdigting van die Psalms het ek gou ingesien hoe fyn die Psalms verloop, oploop, afloop, kortom: hulle loop neem, met hulle indelings in perikope, in diskursiewe segmente, in progressiewe en dialektiese ontwikkelingsfases en dergelike. Vir die Bybelse Psalms geld wat vir elke goeie literêre werk geld, naamlik dat dit 'n georganiseerde verloop het wat, deur duidelik gemarkeerde stadia, in die slot uitloop op ' $n$ ander punt as die beginpunt, selfs as dit met 'n klousuur sluit, want dan het dit nogtans deur sê maar 'n spiraal of watter soort beweging ook al verloop.

\section{- Psalm 8}

Laat ek hierdie georganiseerde handelingsverloop aan die hand van Psalm 8 probeer verduidelik. Psalm 8 verloop in 'n parabool, maar nie in een deurlopende beweging nie: dit begin met die aarde in vs. 2 (vs. 1 dien eintlik as titel en dui aan watter soort Psalm dit is) en dit eindig weer met die aarde in vs. 10, die slotvers. Psalm 8 is daardeur 'n tipiese Psalm wat hom nie net met die hierbomaalse besig hou nie maar ook met die aarde, die hier en nou. Maar, reeds in vs. 2 gaan die Psalm dadelik oor tot die hemelse. In vs. 3 is die Psalm terug by die aardse, naamlik by die mens, en sê dit dat die openbaring van die 
Goddelike so duidelik en onmiskenbaar en eenvoudig is dat selfs 'n suigeling daarvan kan getuig. In vs. 4 is die Psalm terug in die hemelse, by die bopunt van die parabool, en in vs. 5-7 is die digter terug by die aardse, die mens, wat bietjie onder die hemelse gestel is. By hierdie aspek verwyl die digter drie verse lank. In vs. 8-9 trek die Psalmdigter 'n mikro-parabool onder die makroparabool: vs. 8 staan stil by die dinge op aarde om die mens heen: skape, beeste, ander diere, die veld, en in vs. 9 gaan die digter weer hemel toe met die voëls in die lug, en dan gaan hy weer terug na selfs die waters onder die aarde, om met Genesis te praat: visse, see, oseane.

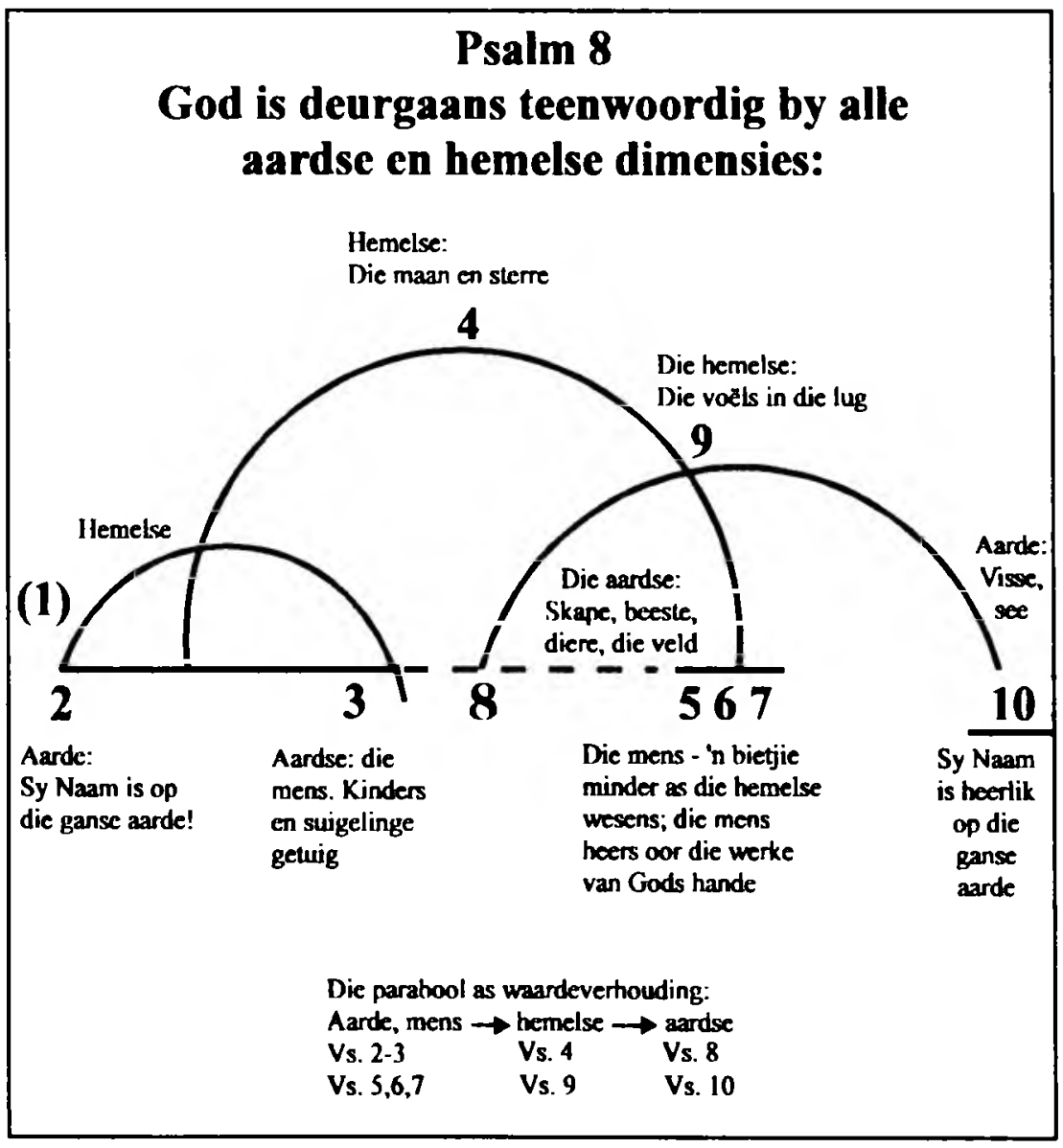

Die wonderlike is egter dat God deurgaans ter sprake is, op watter punt van die parabool jy ook al lees of kyk en met 'n bietjie verbeelding sou ek wou sê dat, as 
ons dink aan dit wat nie aan ons geopenbaar is nie, ons die parabole ondertoe kan deurtrek tot volle sirkels.

Wat doen die parabool? Dit skep waardeverhoudings: die wonderlike van die mens en van die geskape dinge op aarde kry hulle waarde omdat die lyn vanaf die aarde en mens deurgetrek is, werklik deurgetrek is deur die hemelse en toe weer teruggebring is aarde toe, en toe is die Goddelike en hemelse saam teruggebring aarde toe, soos dit in die slotvers staan. Hierdie slotvers is trouens 'n herhaling van die beginvers maar nou met nuwe vulling.

Die digter-bewerker van hierdie Psalm moet in sy omdigting hierdie makro- en mikro-parabole probeer behou, en dit is nie so maklik om te doen as wat dit gesê kan word nie, want daar is so baie ander dinge waarmee hy tegelyk rekening moet hou. Jy is met God en mens besig, met velddiere, voëls, visse, maar jy is met dit alles besig op 'n manier om dit singbaar te maak, en dan plotseling keer 'n simpele ding soos die rym jou voor en dalk vas.

\section{Rym}

Ek kyk slegs na 'n paar dissiplines waaronder die digter-vertaler/vertolker van die Psalms staan.

Die musikoloë, en ook die teoloë met wie ek saamwerk, glo dat die rym onmisbaar is vir die sing van Psalms in ons Protestants-Gereformeerde kerke. As ons kyk na Vader Bonaventure Hinwood se bewerking in Afrikaans van die Psalms en Lofgesange (1993) vir die Rooms-Katoheke kerk, dan sien ons dat die Rooms-Katolieke Kerk anders daaroor dink en voel, want hulle sing anders as die Protestante - lees maar Vader Bonaventure Hinwood se inleiding tot sy omdigtings van die Psalms in die rymlose heffingsvers. Ek het in enkele omdigtings my hand gewaag aan die blanke vers of aan die vers met assonans in plaas van volrym, maar dit lyk my dit vind nie veel byval by die IKKP (Interkerklike Komitee vir die Psalmberyming) nie.

Omdat ons by die Psalms te make het met die lied wat in die erediens en by talle ander, meestal gewyde geleenthede gesing word, is dit nietemin aanvaarbaar dat die rym een van die formele dissiplines is wat gehandhaaf moet word. Die rym word in so 'n mate as belangrik vir die Psalms as kerksang beskou, ook in Nederland byvoorbeeld, dat dit by ons gebruik geword het om van die Psalmgesangeboek as die Psalmberyming te praat. Ek het egter van die begin af voorgestel dat die woord omdigting gebruik word, omdat die rym as klankverskynsel maar een van die magdom dissiplines is waaronder die digter staan en slegs maar een van die baie verdienstes van die rym. 'n Ander belangrike aspek is die formele geledingsgkrag van die rym, of sy semantiese vooropstelling (foregrounding), en baie meer. Nietemin, die rym is inderdaad 
'n verdienste. Dit bly 'n baie belangrike dissipline, en om verskeie redes: die rym is vanself al ' $n$ sterk liriese of melodiese element wat by die sang pas en wat die soniese of foniese krag van die gedig in sy geheel versterk. Die rym is bowendien ' $n$ memoriseringsmiddel vir die aanleer van die Psalmgesange, wat tog by voorkeur geheuebesit van die singende gemeenskap moet wees, behalwe dat dit ' $n$ baie goeie vormdissipline is.

Die rym is egter 'n baie moeilike kalant. Dit is vir 'n digter baie makliker om daarsonder klaar te kom. Die rym lê 'n ontsaglike beperking op die digter se woordkeuse, op sy versbou, op sy hele segging. Die rym sluit talle woorde en woordkeuses vir die digter in sy formuleringsproses en veral in sy versafronding uit, benewens dat die Bybeltaal op sigself al talle woorde vir die digter uitsluit. Die woord liefde kom deurlopend in die Bybelse Psalmboek voor - die digterbewerker sou daardie woord tog seker graag in die klimaktiese posisie van die vers wou plaas ... maar wat rym met liefde? Gegriefde dalk? wat nie 'n Psalmwoord of Bybeltaal is nie. En wat dan nog anders rym met liefde? Byna niks. Dit is vir my amper simbolies: asof die liefde onvergelyklik is, iets absoluuts. So is dit ook met die woord God, of met Heer/Here. By voorbaat sê die musikoloë dat die woord God nie goed sing nie, en as rymwoord duld hulle hierdie woord glad nie - en bowendien rym slegs 'n paar Bybelwoorde daarmee. Gelukkig kom die woord eer/ere in talle Psalms saam met die woord Heer/Here voor, en vir die digter-bewerker wat na rymwoorde soek, is dit 'n uitkoms - hierdie Here/ere wat so gemaklik deur die Bybel vir die digter aangebied word. Tog kan die digter hom ook nie te veel op hierdie rympaar verlaat nie, dan begin dit knal en ruik na retoriek. En hoe dankbaar is die Afrikaanse digter-bewerker nie as hy in die Psalms woorde teenkom wat op -aar, -aal of -ing eindig - vir sulke woorde het Afrikaans 'n ruim aantal keuses as rymwoorde.

Hoewel die rym die digter baie hoofbrekens gee, moet 'n mens dit nie net as 'n belemmering beskou nie. Die rym is, soos dit deur meer as een digter al gestel is, ook ' $n$ bevleugeling, nie net ' $n$ beperking nie: dit bring 'n rykdom van vondste, soos die Nederlandse digter J.H. Leopold dit genoem het.

Tot sover die rym, wat maar een van die baie moeitevolle maar verrykende dinge is wat die digterlike bewerker van die Bybelse Psalms met die oog op die kerksang moet gebruik. 


\section{Die melodie se voorskrifte}

Hier is, om één voorbeeld te noem, die melodie se ingewikkelde voorskrifte vir die bewerker van Psalm 1:

\section{Psalm 1}

Versstruktuur: 10.10 .11 .11 .10 .10 . (d.i. die aantal lettergrepe per vers). Rymskema : a.a.b.b.c.c.

Sesure : tactus-sesure: eindes van versreëls 2,3 en 5 . halwe tactus-sesure: aanvang van frases 2 en 5 . sekondêre sesure: na die vierde lettergreep van elke vers.

Watter geweldige strawwe voorskrif vir die digter-bewerker is die melodieë van die Afrikaanse Psalms nie - dit is 'n amper strawwer voorskriftelikheid as die eksegese. Dit is nie 'n geval dat jy eers jou omdigting maak en dan 'n melodie daarvoor laat skryf nie - die melodie staan daar leeg en wag en jy moet invul. Dit gee in elk geval vir my meer probleme en selfs hoofbrekens as die eksegese. Ons moet ook nie vergeet nie dat die Geneefse melodieë oorspronklik vir Franse tekste geskryf is, en Frans is so onafrikaans as wat kan kom.

Die Bybelse Psalms is deur die Jode van oudsher gesing. 'n Pragtige boek daaroor is Suzanne Haik-Vantoura se The music of the Bible. Die gesonge gedig is trouens 'n oervorm van ons Westerse poësie.

Omdat die in digvorm vertaalde Psalms vandag by ons in die Protestantse erediens gesing word, is dit vanselfsprekend dat die gedig onderworpe is aan die ritmies-metriese en sillabiese verspatroon wat deur die melodie voorgeskryf word, en aan vaste strofeskemas.

Die melodie, afgesien van die baie ander dissiplines waaraan die digter onderworpe is, bind hom op minstens drie, vier maniere:

\subsection{Die verslengte}

Die melodie bepaal die lengte van die verse, dit wil sê die aantal lettergrepe van die verse en die versmaat. Alle melodiē van die Psalms vereis 'n streng metrum. Dit is 'n moeilike opdrag om jou by die lettergreeptelling en die metrum van die melodie te hou, terwyl jy tegelyk voortdurend moet sorg dat jy getrou bly aan wat die Bybel sê. Elke digter sal weet dat 'n baie natuurlike en daarom ideale verslengte die 10 - tot 12 -lettergrepige vers is en dat die ideale, eenvoudiger versmate die jambe en anapes is. Die tienlettergrepige jambiese vers is vir die digter 'n soort ideale ekspressielengte of ekspressievolume, 'n ideale uitdrukkingsruimte of formuleringsruimte. Die jambe en die anapes is die twee versmate wat die Psalms wat ons sing, oorheers. Gelukkig! Van die 
twee is die jambe die maklikste om mee te werk in die omdigting, en die tienlettergrepige jambe (vyfvoetige jambe) is, soos gesê, die hanteerbaarste, maar talle en talle Psalmmelodieë vra 'n korter en selfs baie korter versreël ongelukkig. Ook vra die melodiee selde verse wat ewe lank is; meestal wissel die verslengtes binne die strofe erg drasties. Psalm 38 se melodie met sy sillabiese skema $847 \times 2$ is 'n baie goeie voorbeeld, want die wisselende aantal lettergrepe per versreël, plus die daarmee gepaardgaande ingewikkelde rymskema en die markerings in die Bybelteks is 'n moeilike kombinasie van voorskrifte. Wat moet jy nou doen as jy die woord ongeregtigheid met sy vyf lettergrepe - 'n woord wat so dikwels in die Psalms voorkom - moet inwerk in 'n versreël wat net vier of vyf lettergrepe mag hê, en dan moet daardie vers nog rym ook? Soms vind jy tog 'n uitkoms: die woord belasting (die belasting wat die onderhoriges aan die koning van die Jode moet betaal) het drie lettergrepe, maar jy het net ruimte vir twee lettergrepe - en skielik skiet dit jou te binne dat die woord skatplig met sy twee lettergrepe inpas. Op hierdie manier toets die Psalmbewerking jou woordeskatkamer voortdurend - byna soos vir die man wat blokkiesraaisels invul. Ek het op 'n keer 'n artikel van 'n Engelse taalkundige gelees wat die lof besing van die eenlettergrepige woord. Ek het geleer om op my knieë van dankbaarheid te gaan vir die eenlettergrepige woord en sy inskiklikheid - ek bedoel dit letterlik - sy diensbaarheid en bruikbaarheid by die bewerking van die Psalms.

As digter-bewerker van die Psalms moet jy voortdurend dit wat daar staan Skriftuurlik getrou inpas, aanpas, pas en meet. Kyk na Psalm 47 met sy vyflettergrepige verse. Hoe korter die verslengte is, hoe moeiliker word die digter se taak in die omdigting. Die digter moet versmatige uitdrukkingsruimte of -lengte hê - 'n gegewe wat die te kort sillabiese versreël van die melodie plus . rym hom nie sommer so al te maklik bied nie. Die voorskrif van die verslengte is nog moeiliker as die verse van die strofes nie almal ewe lank is nie. Dit op sy beurt maak die rym moeiliker, omdat 'n sê 8- of 4-lettergrepige vers immers nie mag rym met 'n sê 5-lettergrepige vers nie - 'n 5-lettergrepige vers moet met 'n 5 rym en kan nie met 'n 4 of 8 rym nie, volgens die melodie. Die melodie kan die digter-bewerker op baie maniere letterlik na sy pype laat ronddans met die vers. Kyk byvoorbeeld na Psalm 67 waar die melodie die digter dwing om van die jambe na die anapes oor te spring, of Psalm 33: 


\section{Psalm 33 - dwang van die melodie om van jambe na anapes oor te spring}

In hierdie grafiese voorstelling verwys die syfers na die sterk wisselende lettergreeptelling en die verbindingslyne verwys na die ingewikkelde rympatrone:

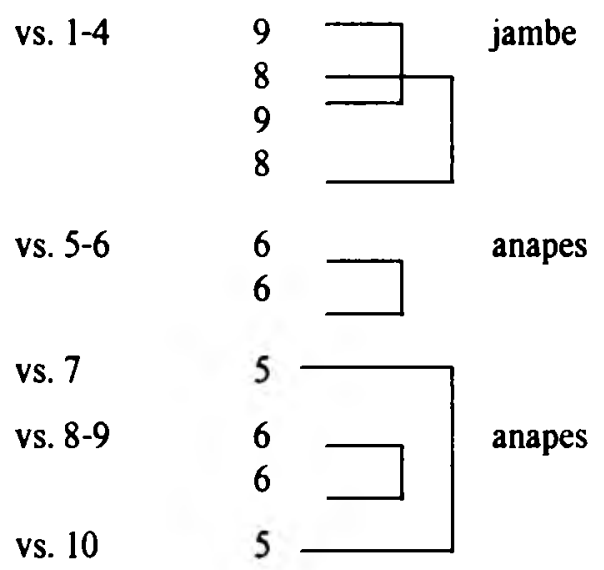

Wat ek hiermee alles wil sê, is dat daardie Psalms wat ons gereeld so heerlik vlot en jubelend sing, met baie hoofpyn, kopkrap, hartpyn en selfs met fisieke vermoeienis tot stand gekom het. Ek wil egter vinnig bysê, met nadruk en met herhaling: dit is 'n heerlike werk, 'n kreatiewe avontuur.

\subsection{Die strofelengte}

Soos die melodie die sillabiese lengte van die versreël voorskryf, skryf dit ook die lengte van die strofe voor - en vanselfsprekend vereis die melodie dat die strofes van 'n bepaalde Psalmgesang almal ewe lank moet wees. Sekere strofevorme is deur die eise of aard van die melodie uitgesluit in ons kerksang. Die kwatryn is die kleinste gewenste strofevorm vir 'n omgedigte Psalm. Die koeplet as strofe is uitgesluit, om verstaanbare redes: dit moet (vir die Protestantse oor, in elk geval) 'n taamlike geneurie afgee om so 'n kort melodie oor en oor te herhaal. (Die Rooms-Katolieke met hulle kantilering (chant) of neurie-sang sing anders as die Protestant, en daarom is Vader Bonaventure Hinwood se bewerking van die Psalms so anders as ons s'n.) Ook die tersine is uitgesluit vir die nuwe omdigting. In ons Totiaanse Psalmboek is daar, as ek goed gekyk het, net 'n enkele tersinestrofe, naamlik die tweede strofe van Psalm 133. Die eerste strofe het ses verse. 
Langer strofes, byvoobeeld die 8-reëlige, gee die digter meer skopus as die kwatryn byvoorbeeld. Die langste strofe in Totius se beryming is 13 verse, soos deur die melodie gevra. Maar wat doen die digter-bewerker as hy alles wat in die Bybelse Psalm staan, omgedig het en sê nou sy 13-reëlige slotstrofe is nog nie vol nie? Ek wens ek het raad daarmee geweet. Die korter strofe weer, die kwatryn byvoorbeeld, is dikwels volgeskryf voordat 'n bepaalde segment, gedagte, vers of versegroep van die Bybelse Psalm ingewerk of ingedig is.

Met hierdie opmerking het ek aangeland by die verskynsel dat die melodie altyd vereis dat die verse van elke strofe gegroepeer word in substrofes, elkeen met sy eie rymketting, wat 'n nogal strawwe beperking vir die digter is - 'n nogal lastige dwingeland hierdie.

Elke melodie van ons Psalmgesange, sonder uitsondering, skryf voor dat die versreëls van elke strofe, hoe kort die strofes ook al is (byvoorbeeld die kwatryn), gegroepeer moet word tot kleiner substrofes van byvoorbeeld $2+2$, $2+2+3,3+3,2+3+4,2+1+2+1-$ 'n byna onoorsigtelike aantal kombinasies. Die melodie bepaal wat die kontinuiteit of diskontinuiteit (pouses) tussen verse onderling in 'n strofe moet wees. Ek neem Psalm 121 as voorbeeld. In elke strofe is die subgroepering van die verse ideëel-sintakties-prosodies deurlopend so: i-iii (ruspunt) iv (ruspunt) v-vi (ruspunt).

Die ideaal vir ' $n$ homogene strofe is dat die digter moet sorg dat elke strofe van elke Psalm ' $n$ ideēle eenheid is - en daarmee saam natuurlik ook 'n strukturele/ formele en sintaktiese eenheid. Hierdie eis geld selfs in 'n groter mate vir die substrofes of binnestrofes. Dit is gebruik in ons eredienste en by ander geleenthede dat dikwels net sekere strofes van 'n Psalm gesing word, miskien selfs net een enkele strofe, in plaas van die hele Psalm. Hierdie gebruik maak dit wenslik dat 'n strofe nie sintakties-inhoudelik (vanaf strofe 2 natuurlik) op "En/en" of "Want/want" of 'n ander dergelike teruggrypende koppeling moet begin nie. In ons bestaande Psalmboek laat Totius in Psalm 104 strofe 4 oorloop in 5 - maar dit is die uitsondering. (Slotverse van strofe 4: "Die waters in hul stormgewoel,/ oor hoogste berge heengespoel,"// (beginverse van strofe 5:) "het $U$, soos in 'n vegtersvlaag,/ deur donder voor $U$ heen gejaag".)

\subsection{Melodie, woord-toonverhouding en singbaarheid}

Die melodie, die singbaarheid van die Psalm, stel baie ander eise. So het ek van die musici geleer dat daar besware bestaan teen die gebruik van byvoorbeeld die woorde heskerm en ontferm met die veronderstelling dat dit, deur die invoeging van die svarabhaktiklinker, as drie in plaas van twee lettergrepe gesing kan word. terwyl dit moontlik is om reën of seën as een of twee lettergrepe te sing. 
Dan moet mens in die geval van sekere woorde rekening hou met die versposisie van daardie woorde. Wat poëties en taalkundig normaal en mooi klink, is nie altyd singbaar nie, en die behoud van dieselfde woorde maar met geringe verskuiwings maak die vers dikwels meer singbaar. Wat 'n lastige saak is, is wat genoem word die woordtoonverhouding. Dit gaan naamlik daarom of 'n bepaalde woord in ' $n$ metries swak of sterk beklemtoonde posisie staan, of wanneer ' $n$ kort noot op 'n lang lettergreep gesing moet word of 'n lang noot op 'n kort lettergreep, of 'n sogenaamde swak woord, soos byvoorbeeld die onbepaalde lidwoord, op 'n sterk noot gesing moet word. Dit gaan daarom dat woorde wat normaalweg nie 'n klem kry nie, nie op 'n hoë noot gesing kan word nie. Vergelyk die woordtoonverhouding by die woorde ganse $(r)$ elke keer in die beginverse in Psalm 9, Psalm 24, Psalm 111 en Psalm 138 in die Totiusberyming. Volgens die opvattings van die musikoloë in die IKKP is die woordtoonverhouding van ganser in die eerste vers (eerste melodie) van Psalm 9 nie melodies-gemaklik nie, omdat die lettergreep /-ser in die gewone skandering swak beklemtoon word maar in die melodie op 'n hoë noot gesing moet word; in die tweede melodie van Psalm 9 is die "ganser" egter aanvaarbaar geplaas. In Psalm 24 en 111 is die "ganse" in orde, maar in Psalm 138 weer nie. Die woord-toonverhoudinge stel voorskrifte aan die digter wat nie in die gewone digkuns bestaan nie.

In ander gevalle vind musikoloë dat die te digte opeenvolging van sekere woorde nie lekker sing nie, soos byvoorbeeld die " $u$ " in "strek $U$ u hand oor my uit", of dat die opeenvolging van sekere klanke uit die Afrikaanse keel onmelodies klink, soos byvoorbeeld die opeenvolging van te veel g's.

Dit is slegs enkele van die eise en probleme wat die melodie aan die digter stel.

\section{Wat en hoe}

Ek het reeds gesê dat vir die verstaan van die Bybelse Psalms geld wat vir elke literêre werk geld, naamlik dat ons alleen kan verstaan wat daar staan as ons insien hoe dit daar staan. Pas toe ek begin het met die omdigting van die Psalms, het ek, in baie gevalle deur die oë van die eksegete, ontdek hoe fyn gestruktureer die Psalms is: die indelings in perikope, in diskursiewe segmente, in progressiewe en dialektiese ontwikkelingsfases en dergelike.

Ek kan Psalm 88 as voorbeeld noem. Ridderbos (1955,Il:361) wys uit hoedat daar drie afdelings in die Psalm is: elke afdeling begin met bid of "roep", gevolg deur klaagverse: I vs. 2-10, II vs. 10b-13, III vs. 14-19. 


\subsection{Die strukturering van die Psalms}

Ek het vroeër daarop gewys dat die digter-bewerker van die Psalms met die oog op die kerksang daarmee moet rekening hou dat die Psalms fyn gestruktureer is. Die digter-bewerker van die Psalms moet gevolglik nie alleen sorg dat die perikope, die subeenhede, segmente of fases van die Bybelteks strofies afgerond bewerk word nie, maar hy moet bowendien sorg dat hulle gelykberegtig word in die aantal strofes wat hy aan elkeen van so 'n perikoop of subeenheid of segment afstaan. As 'n bepaalde perikoop of segment van die Bybelse Psalmteks nie 'n strofe of groep strofes tot die laaste vers vul nie, mag die digter nie "aanvul" soos hy wil nie.

Ek neem Psalm 148 as voorbeeld. Prof. W.S. Prinsloo (1991:112) het in sy eksegese aangedui dat daar ' $n$ byna presiese tweedeling in dié psalm bestaan eers word die hemelinge beveel om God te prys (vs. 1-6), daama word die aardlinge beveel om Hom te loof (vs. 7-14). In die omdigting behoort hierdie tweedeling so goed moontlik in die aantal strofes in gelyke mate tot sy reg te kom.

Op grond van wat ek reeds gesê het, is dit duidelik dat dit 'n vereiste is dat die digter die oorspronklike Hebreeuse teks se struktuur voortdurend in gedagte moet hou. Dink ook aan die tweelingpsalms 111 en 112, wat ewe lank is. Psalm 111 beveel die mens om God te dien, en 112 gee dan die profiel van die mens wat God dien soos 111 dit voorskryf, soos die eksegeet (W.S. Prinsloo, 1991:112) dit stel. Die digter moet hierdie soort tweelingskap baie beslis behou. In die geval van Psalm 96, 97 en 98 het ons met 'n eskatologiese trilogie te make, en die digter-bewerker moet die trilogiese aard probeer behou tot in die fynste detail, hoe moeilik dit ook al is. Kyk byvoorbeeld na die volgende herhaling in dié trilogie: in Psalm 96:8 staan daar: "Prys die Here ... kom na sy voorhowe toe". In Psalm 97:11 lees ons: "Vir die regverdiges het daar lig gekom". In Psalm 98:9 staan daar dat alles moet juig voor die Here, "want Hy kom om oor die aarde te heers". Ps. 24 weer (ongepubliseerde eksegese van prof. C. Vos), is ' $n$ goeie voorbeeld van die beurtsang wat in die Psalms voorkom. In die omdigting moet die beurtsang behou word.

\section{- Psalm 121}

'n Ander goeie voorbeeld is die drie konsentriese sirkels in Psalm 121 (eksegese van prof. W.S. Prinsloo, 1988:103). In die wydste, alles-omvattende sirkel is God (vs. 1-2). Dan word daar beweeg na die kleinste sirkel: jy, ek, die enkele mens (vs. 3); dan word daar 'n sirkel getrek tussen die buitenste, omvattende Goddelike sirkel en die binnenste, individu-sirkel, as daar in vs. 4 na Israel verwys word, en ten slotte, in die res van die Psalm, vanaf vs. 5-8 word daar teruggekeer tot en verwyl in die kleinste sirkel, die binnesirkel, waar die 
individu, jy/ek, betrek word. Wat sê hierdie drie konsentriese sirkels? God, die alles omvattende, insluitende, beskermende wydste kring, God as Skepper van hemel en aarde, is in die kleiner kring daarbinne die beskermer van Israel, en in die derde, binneste kring word die enkeling onder die sorg van God gesien. Hy wat hemel en aarde gemaak het, Hy kan 'n hele volk, as 'n versameling enkelinge, beskerm, en Hy wat hierdie groot mag het, kan ook vir jou, die enkeling, beskerm. Maar let weer op, net soos in die parabool van Psalm 8 is God in al die kringe aanwesig:

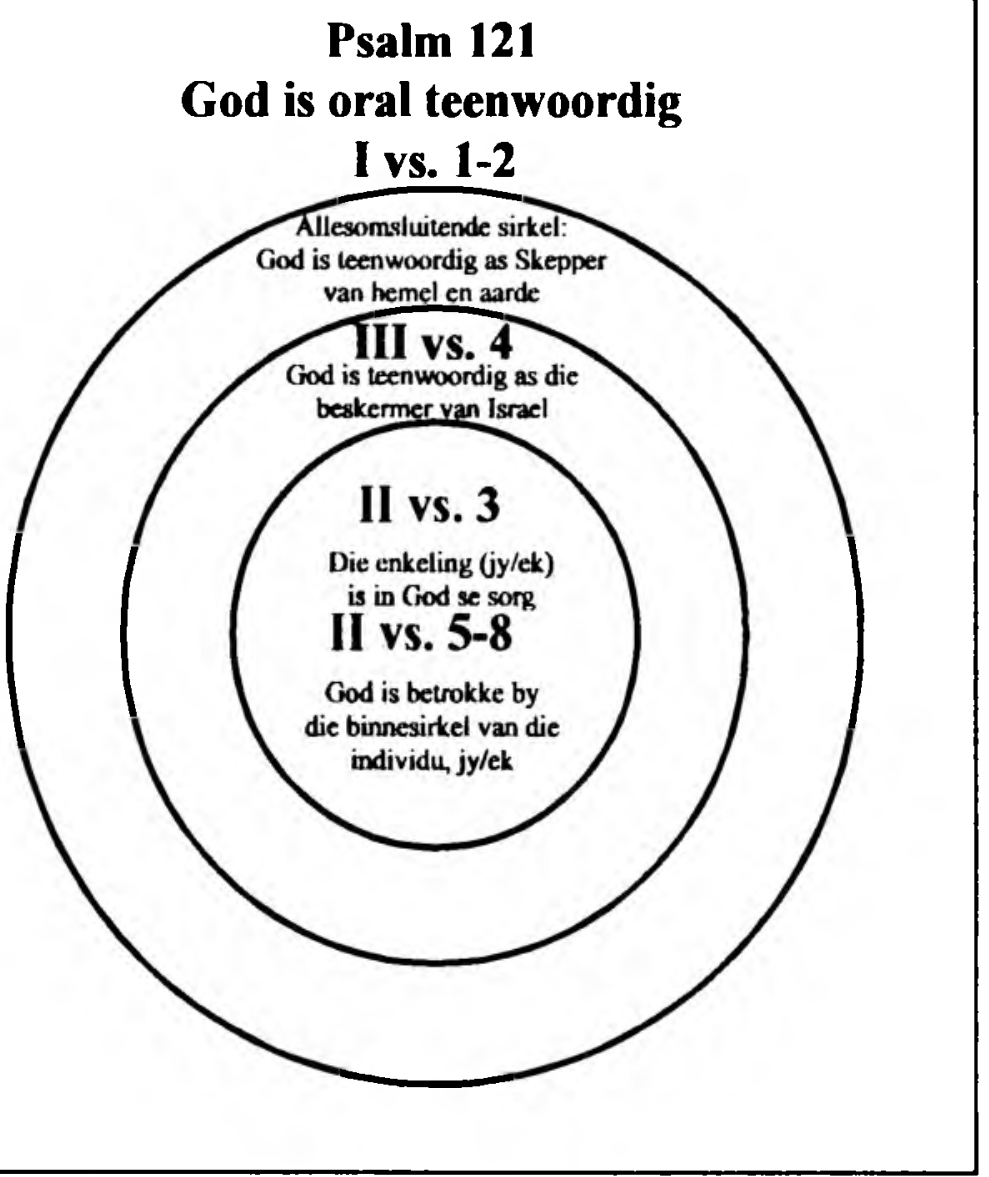

Die oortuigingskrag van die Psalm lê in hierdie drie konsentriese sirkels, en hierdie struktuur moet so goed moontlik behou word in die omdigting, want dit 
gee elke keer reliëf aan die drie hoofbewegings in die Psalm. Dit is vir my elke keer 'n openbaring om te ontdek hoe sinvol die Psalms verloop.

Daar is ook die kwessie van die volgorde van sake in die verloop van die Bybelse Psalms. Die eksegeet en digter moet uitmaak hoe dwingend die volgorde van die komponente of gegewens (van watter aard ook al) van die Bybelse Psalmteks is - ons moet ons afvra of die Bybelteks geweld aangedoen word of tekort gedoen word as die volgorde van die gegewens van die Bybelteks verander word. 'n Eenvoudige, vanselfsprekende voorbeeld: as die Bybelse lofpsalm eers die motivering vir die lof gee en daarna die lof bring, mag die digter dit sekerlik nie omkeer nie. In Psalm 148, waama ek reeds verwys het, mag die digter sekerlik nie die volgorde van die aangesproke hemelinge en aardlinge gaan omruil nie. Of dink aan 'n klein maar belangrike detail soos in Psalm 104 vers 19: "U het die maan gemaak om die vaste tye mee aan te gee, die son weet wanneer om onder te gaan". Die eksegeet wys uit dat daar 'n duidelike rede is waarom die maan eerste genoem word en die son tweede. Hierdie volgorde moet behou word, omdat die dag volgens die Israelitiese jaartelling (luni-solêre kalender) met sonsondergang begin het. 'n Mens kan ook kyk na Psalm 136. Die eksegese (W.S. Prinsloo, 1991:91) dui aan hoe daar 'n sekere geleding in die Bybelse Psalm is: 1-3 (oproep tot dank), 4-9 (Jahwe as Skepper), 10-24 (Jahwe as Verlosser) en 25-26 (samevatting en oproep tot dank), weer eens 'n duidelike, onveranderbare struktuur wat die digter moet respekteer. Die Prediker (3:14) sê: “... wat God doen, is blywend: jy kan daar niks byvoeg nie en jy kan daar niks van wegneem nie". Hy sê niks van verskuif nie. Die omdigter kan alleen wegneem, toevoeg of skuif as dit nie verdraai nie.

Onder die baie struktuurelemente wat die omdigter moet gehoorsaam, is daar byvoorbeeld nog die parallelismes wat in baie Psalms voorkom, teenstellings, sekere essensiële herhalings, Leitmotiven (soos die waterbeelde in Psalm 88).

'n Interessante struktuurverskynsel wat dikwels in die Psalms voorkom en wat deur die digter-bewerker skerp in gedagte gehou moet word, is iets soos die grammatikale tyd van die Psalms, iets soos byvoorbeeld die perfecta confidentiae, waarvan ons 'n voorbeeld in Psalm 20 vind: die Psalm het twee dele: deel I (vs. 1-6) is 'n gebed, deel II (vs. 7-9) spreek die sekerheid uit asof die gebed reeds verhoor is, en dit is die grammatikale tydsvorm wat dit sê. Daar is ander dinge soos afwisselend die aanspreek van God en van die mens/gelowige; die afwisseling van ons/ek, van enkelvoude en meervoude, ensovoorts.

\subsection{Getrouheid aan die Bybelse woord?}

Ek het probeer duidelik maak dat die omdigter so getrou moontlik moet bly aan die Bybelse Psalm en dat Skriftuurlike getrouheid tegelyk beteken strukturele 
getrouheid. Ek sê: so getrou moontlik. Maar daar is soorte getrouheid. Skriftuurlike en strukturele getrouheid is baie dwingend, maar kan die digter getrou bly aan elke woord van die Bybelse Psalm? Dit is nie moontlik nie. Lees byvoorbeeld naas mekaar: Totius se bewerking, die Nederlandse Interkerklike bewerking, Gabriël Smit s'n (1957) en Vader Bonaventure Hinwood s'n (1993), en kyk hoe verskil hulle onderling, al is hulle almal Skriftuurlik getrou. Woordelike getrouheid is nie moontlik nie en selfs nie wenslik nie. Vir die digter-bewerker van die Psalms is dit dikwels 'n groot probleem, want wat moet hy dan behou van die Bybelse Psalm en wat mag hy weglaat? Ek het reeds gesê dat die Skrif, die melodie en veel meer sake, baie taalgebruiksmiddele en digterlike gebruike vir die digter uitsluit, net soos die Bybel hom dwing tot insluiting, maar die digter sélf, op sý beurt, kan of moet selfs in baie opsigte uitsluit. Ek wil nie op Totius kritiek uitspreek nie, maar ek wil in die verbygaan tog daarop wys dat hy soms meer omgedig het as wat nodig is, al is dit na die patroon van sy Nederlandse voorbeelde. Ek noem dit net om te sê ons moet daaruit leer. Totius se omdigting van byvoorbeeld Psalm 87 is, as ek dit so mag noem, relatief gesien langer as die Bybelse Psalm. Ek vind dit ook by Psalm 65. Totius het soms te veel strofeleegtes "gevul", maar dan het hy ook soms te veel omgedig van wat wél in die Bybel staan. Ek dink nie dit is nodig om elke woord wat in Psalm 119 staan om te dig nie, maar dit geld ook vir talle korter Psalms. Hoe meer die digter daarna streef om alles van ' $n$ besondere Psalm te wil behou in die omdigting, hoe meer word hy gedwing om by te dig om sy strofes te vul, maar hoe meer hy hom tot die verteenwoordigende of eksemplariese beperk, hoe minder word hy verlei tot bydigting. Die digter moet nie te veel wil doen nie. Psalm 146 is 'n goeie voorbeeld: in vs. 7, 8 en 9 noem die Bybel verskeie maniere van hoe God verlos, vry maak, beskerm, genees en onderhou. Dit is myns insiens nie nodig dat al hierdie "items" in 'n omdigting genoem word nie. Dit kan ewe goed saamgevat word in wat ' $n$ mens mag noem sekere verteenwoordigende voorbeelde. Waar dit gaan om weglaat, moet die bewerker egter hoogs versigtig wees. Dink aan Psalm 72:8-11, waar die name die windrigtings aandui. Dis nie sommer net name nie. Dink in hierdie verband ook aan Psalm 89:12-13: net die noorde en suide word genoem as skeppinge van God, maar die Tabor en die Hermon wat daama genoem word, staan vir die weste (Tabor) en ooste (Hermon) en moet behou word in die bewerking.

Wat soms na blote beelde lyk, is wel beelde, maar vol seggingskrag vir wie reg lees. In Psalm 92:13 word gesê dat die regverdiges sterk sal wees soos palmbome en soos die hoë seders van die Libanon. Dit is nie sommer 'n vergelyking vir die fraaiheid daarvan nie. Hierdie twee bome is "twee koningen onder de boomen" (Ridderbos, 1955, II:410), die eerste in die vlakte, die tweede op die berge, albei immergroen, albei oud, met deursettingsvermoë, standhoudende 
groeikrag en bloeikrag - eienskappe wat die goddelose nie het nie. Wat vir ons na geringe sake mag lyk, is nie altyd so gering nie, byvoorbeeld dat pyn in die murg en gebeente meer intensief is as pyn van die vlees, omdat die murg en gebeente dieper lê as die vlees (Ps. 38:4; vgl. die Ou Vertaling).

\subsection{Die idiolek van die Bybel en 'n moderne Afrikaanse omdigting}

Die digter moet hom natuurlik ook by die idiolek van Bybel hou, maar in hoe 'n mate? Ons hoor nou al teoloë en gemeentelede sê: julle moet in die nuwe bewerking nie alleen die Totiaanse argaīsmes vermy nie, maar ook sekere Bybelse woorde soos tempel of gramskap. Sekere Bybelse woorde bly egter uniek in hulle betekenis. Ek dink aan die gebruik van die woord verhoor. "Verhoor" is 'n deur en deur Bybelse woord, die gebruik waarvan byna net in die Bybel in sy besondere betekenis voorkom, en natuurlik in die prediking, in gebede en in ander Bybelverwante taalgebruik. In die regstaal, waar dit ewe veelvuldig voorkom, beteken "verhoor" iets totaal anders.

Terwyl ek oor die taal van die Bybel praat en van die nuwe Psalmgesange, is dit die plek om te sê dat 'n nuwe omdigting nodig is vir die Afrikaans van vandag, 'n Afrikaans wat sedert Totius se beryming in baie opsigte verander en gegroei het in poëtiese krag. Die nuwe bewerking is 'n taaltoets vir Afrikaans.

Die Afrikaanse literatuur se herkoms lê deur ons taalgeskiedenis in die Nederlandse taal en literatuur. In die Nederlandse taal is die omdigting van die Psalms ' $n$ integrale deel van die ontwikkeling van daardie literatuur sedert die Wachtendonkse Psalmen, 'n Oud-Nederlandse Psalmvertaling uit die IOde eeu, wat beskou word as een van die eerste literêre toetse van die Nederlandse taal. Dit geld ook vir die Nederlandse Bybelvertaling; daarom dat die romanskrywer Arthur van Schendel in "Bij het uitpakken van de boeken" gesê het die Bybel word heel laaste uitgepak, want dit is eerste ingepak met die verhuising.

$\mathrm{Na}$ die Wachtendonkse Psalmen volg die Souterliedekens van Willem van Zuylen van Nyvelt van 1540, daama Datheen se eenvoudige bewerking uit 1566 , dan Mamix in 1580, Camphuysen in 1630, Vondel in 1657, en so loop dit deur tot in ons eeu met Nijhof se Psalmberymings en Gabriël Smit s'n. Van baie onlangs is daar die pragtige Psalmen wat deur J. Kousemaker (1981) verzeeuws is. Baie van hierdie omdigtings is uit vrye literêr-kreatiewe wil en nie vanuit kerklike opdrag gedoen nie. Die Nederlandse beryming van 1773 was eeue lank in gebruik. In 1958 is 'n interkerklike kommissie van teoloē. digters en musikoloë in Nederland gestig om 'n nuwe beryming op die ou 
melodieë te maak. Totius se beryming is in 'n groot mate 'n vertaling uit die Nederlandse Psalmbewerkings en is vandag deel van ons literatuur. ${ }^{3}$

\section{Psalmsang en deelname}

Die omdigting van die Psalms, van meet af aan, op grond van die Nuwe Bybelvertaling, soos dit tans in die vooruitsig gestel word, is 'n baie moeilike taak, 'n "Herculesarbeid", soos dit al genoem is. Dit is 'n taak wat baie geduld en baie begrip vra, en dit is ' $n$ nodige taak, omdat die Psalms so ' $n$ belangrike deel van ons erdediens vorm. Wanneer die leraar voorlees uit die Bybel, wanneer hy bid, wanneer hy formuliere lees en dergelike, doen die gemeentelid mee, maar luisterend, in stilte.

\section{- Aktiewe deelname aan die erediens}

Wanneer 'n Psalm egter gesing word, is dit vir die gemeentelid die geleentheid om self, mondeling en hardop, mee te doen. Dan mag die leraar maar sy mond vir 'n tydjie hou. Die sing van Psalms of ander gesange is dus nie daar om bietjie litte te rek of asem te skep nie.

Wanneer die gemeentelid die Psalms sing, doen hy mee aan iets wat in die ou tyd reeds in gebruik was; hy doen mee aan 'n baie ou soort sangteks of singmateriaal, duisende jare oud, 'n ou besit wat deur die eeue heen die toets van die tyd weerstaan het, ook in baie ander tale, lande en tye en hy doen mee aan iets wat gelaai is met geskiedenis en gewydheid.

- Die Psalms ontsluit emosies, rig ons in ons verhouding tot God en medemens

Die Psalms is vir die gelowige belangrik omdat dit so 'n ryk scala van emosies, gevoelens en ervarings bevat, van die individu, van 'n volk, van die gelowige gemeenskap, van die totale menslikheid, soos beskryf in Psalm 90. Daar is al gesê dat die Psalms die ganse scala van menslike gevoelens bestryk, van skuld en boete, van vergifnis en blydskap en verlossing, van aanbidding en

3 Die Totiusberyming is nie alleen vandag vir die Afrikaner (veral vir jongmense en kinders) in baie opsigte onverstaanbaar vanweë die baie argaismes en Nederlandismes nie, dit is bowendien in 'n baie groot mate 'n vertaling uit of navolging van die Nederlandse 1773-beryming, wat lankal in Nederland self as verouderd en nie meer bruikbaar nie gevind word en byna ' $n$ halfeeu gelede al vervang is deur 'n nuwe beryming. Trouens, die Totiusberyming gaan in sekere van sy bewerkings op Nederlandse tekste terug wat nog veel ouer as die Nederlandse 1773-beryming is. Ons sing met ander woorde vandag in Suid-Afrika 'n beryming, gebaseer op Nederlandse bewerkings, wat in Nederland self lankal nie meer gebruik word nie. 
verguising, van trots en deemoed, vrede en onrus, opstand en berou, van wanhoop en uitkoms, pyn en saligheid. Die Psalms plaas ons in ons aardse omgewing, onder die hemel, in ons verhouding tot ons medemens en ten slotte in ons verhouding tot God. Dit is soms selfs gerig op die eenvoudige dinge van die realiteit, soos Psalm 104. Die Psalms bevat die rykdom van God se openbaring, en selfs kinders kan dit verstaan, soos dit in Psalm 8 gestel word. Psalm 8 is ' $n$ byna samevattende soort psalm, met die parabool wat dit teken in sy drie dimensies.

\section{- Toe toepaslikheid van die Psalms - ook vir vandag}

Ten slotte lê die waarde van die Psalms in hulle toepaslikheid op ons, ons, soos ons vandag hier in Suid-Afrika leef - en dit moet dan in Afrikaans gesê kan word. Die Psalms is oud, maar ook hedendaags, geldig vir nou, hier, op ons, op my. Depressiwiteit word gesien as modeme siekte van die mens, maar die Psalms het dit al beskryf in Psalm 6 en 88, met raad hoe om daarvan verlos te word, naamlik om dit voor God te noem en te beskryf. Ons soek vandag 'n nuwe volkslied vir die nuwe Suid-Afrika. Wat van Psalm 72, wat 'n wonderlike model vir 'n volkslied is? Of wat van Psalm 44 as beskrywing van 'n land in sy verval? En vir myself, as individu, is Psalm 38 amper 'n biografiese psalm. So ook is Psalm 90 elke gelowige se biografie.

\section{Ten slotte}

Die omdigting van die Psalms as kreatiewe werk verg ingespanne arbeid, maar die uitkringende dimensies wat deur hierdie werk geopen word, vul die digtervertolker by herhaling met verwondering en nederigheid.

Om besig te wees met die omdigting van die Psalms gee aan die digter- vertolker die unieke geleentheid om fyn ingestem te word op die kleinste nuanse van struktuur, woordbetekenis en formulering - aspekte wat uiteindelik ook ontsluitend werk in die waarneem van die Godsopenbaring wat in die woorde skuilhou.

\section{Bronnelys}

HINWOOD, BONAVENTURE. 1993. Psalms en lofgesange. Pretoria: Van Schaik.

KOUSEMAKER, J. 1981. 'n 'Andvol Psalmen. Middelburg : Fancy Boeken.

PRINSLOO, W.S. 1988. Van kateder tot kansel. Pretoria : NG Kerkboekhandel.

PRINSLOO, W.S. 1991. Die Psalms leef. Pretoria : NG Kerkboekhandel. RIDDERBOS, J. 1955. De Psalmen I en II. Kampen : Kok.

SMIT, GABRIEL. 1957. De Psalmen. Utrecht-Antwerpen : Prisma-Boeken. 
